\title{
THE IMPACT OF FLIPPED CLASSROOM APPROACH ON THE WRITING ACHIEVEMENT AND SELF-REGULATED LEARNING OF PRE-SERVICE ENGLISH TEACHERS
}

\author{
Dr. Ezgi Aydemir ALTAS \\ ORCID: 0000-0002-0460-3322 \\ School of Foreign Languages \\ Yildiz Technical University \\ Istanbul, TURKEY \\ Dr. Enisa MEDE \\ ORCID: 0000-0002-6555-5248 \\ Faculty of Educational Sciences \\ Bahcesehir University \\ Istanbul, TURKEY
}

Received: 19/12/2019 Accepted: 28/05/2020

\begin{abstract}
The major purpose of this study is to investigate the impact of flipped classroom on pre-service English teachers' Advanced Writing achievement. The study also aims at exploring whether flipped classroom approach makes a difference, if any, on the self-regulated learning of the participants. The participants of this study were selected by convenience sampling method and consisted of fifty-five $(N=55)$ pre-service ELT teachers attending Advanced Writing course and studying at English Language Teaching Department (ELT) at a foundation university in the fall semester of 2017-2018 academic year. Two intact classes were selected as control $(N=28)$ and experimental group $(N=27)$. The control group was exposed to traditional lecture based instruction, whereas the experimental group received the flipped classroom approach. In this quasi-experimental study, data were gathered through pre-post-tests of advanced writing and self-regulated learning scale. Mixed ANOVA analysis was used for data analysis. The obtained results demonstrated that the implementation of flipped classroom approach resulted in better writing achievement, yet self-regulated learning showed no significant difference between groups. Based on these findings, the study provides pedagogical implications and suggestions for integrating flipped classroom approach in the undergraduate programs.
\end{abstract}

Keywords: Flipped classroom approach, self-regulated learning, ELT, writing achievement

\section{INTRODUCTION}

Writing is considered as a cognitively challenging task which is not learned naturally (Pavanelli, 2018). As writing is quite complex and is affected by "layers of context", successful academic writing teaching is mainly based on a complete comprehension of the challenging nature of writing in academic settings, and considering faculty perceptions on academic writing and writing instruction shows efforts to comprehend one part of the complexity (Zhu, 2004).

However, for most Turkish foreign language learners, writing is one of the hardest skills to accomplish as they lack of adequate and necessary knowledge. They are expected to reach a proficient level of English in order to comprehend the course content in their departments and write essays at a good level. Yet, improving the writing performance of the learners is an issue for most teachers as they face problems regarding the materials, design of the course, timing, allocating time for feedback etc. Therefore, students are expected to be self-regulated learners in order to manage their own learning process, which could help both the instructor and the learners to use their time more efficiently and fulfill the necessities of the course. Lastly 
and most importantly, students need to receive ample feedback regarding their writings to be able to review and reflect on their own academic writing, which also requires students to practice profoundly, collaborate with their peers, self-correct based on the reflections they receive from their teachers (Pavanelli, 2018). However, the time allocated for lecturing during the traditional lecture based instruction restricts the time that could be used for more practice and feedback, which in turn results in not being able to use the class time as efficiently as expected or desired.

Therefore, in order to eliminate such problems and improve learning process recent trends in education attempt to reinforce student-centered instruction which enables students to take control of their own learning via establishing a learning environment where they are encouraged to participate, think critically, improve their problem-solving skills, engage in various activities, work collaboratively, and form meaningful interactions rather than memorizing and being passive learners (Alsowat, 2016). Over the past two decades, there have been immense changes regarding instructional technology and how teachers perceived the role of technology in education, which enabled the teacher to allocate more time for in-class activities and use the technology to enable a supportive, manageable and personalized learning environment (Wiginton, 2013). Furthermore, considering the fact that students frequently use technology in various ways, teachers have been integrating technology into their teaching in order to keep up with the recent trends and the needs of the students. One of these technologies is the blended learning which is a combination of face-to-face and online interactions (Alsowat, 2016). Blended learning can be defined as combining face to face learning and electronic or distance learning, making use of different learning theories, methodologies and techniques in a single place and promoting learning with numerous online technologies throughout the learning process in the classroom (Rossett, Douglis, \& Frazee, 2003; Singh, 2003; Neumeier, 2005). According to Rasmussen (2003), blended learning is a distance education method involving the use of technology combined with traditional education and teaching. Horton (2000) stated that "combining more strong and advantageous aspects of online learning and the learning in classroom" is the fundamental target of blended learning and it was also stated that "blended learning provides the opportunity to integrate advantages offered by online learning with the best practice and benefits of traditional learning" (Tselios, Daskalakis, \& Papadopoulou, 2011, p.225) In parallel with the descriptions so far, Trinder (2012) claimed that blended learning is "a combination of face-to-face and online learning, with usually one of the two functioning as a lead mode" (p.1). However, George-Walker and Keefe (2010) argues that blended learning is beyond a simple combination of new knowledge and interaction technologies with face-to-face activities. It is rather an "organic integration of thoughtfully selected and complementary face-to-face and online approaches and technologies (Garrison \& Vaughan, 2008, p. 148). In a sense, it reaps the advantages of both face-to-face and online learning environments. Therefore, it can be stated that blended learning requires a harmonized and meticulous design of teaching in order to make the best use of both traditional and online learning. In this regard, the necessity of teacher student interaction both with and without the use of technology was emphasized (Garrison \& Vaughan, 2008; Tselios, Daskalakis, \& Papadopoulou, 2011). Blended learning aims at enhancing student learning and promoting learner-centered paradigm (Shibley, 2014). Blended learning has gained significance considering the latest trends in education and a growing body of research comparing the differences between blended learning and traditional face-to-face instruction considering their effect on student achievement has revealed that blended instruction is quite more effective than the other one (Barkley, 2010; Condie \& Livingston, 2007; Means, Toyoma, Murphy, Bakia, and Jones, 2010; Watson, 2008). Along with the latest improvements in technology, creating and streaming high definition videos via comparatively inexpensive devices through cellular and wireless networks has contributed to the development a new type of blended learning (Quint, 2015). Resulting from the increase in technology options to be integrated into education, the flipped classroom is one of the options of applying new ideas in schools and classrooms (Kenna, 2014). Flipped classroom approach is a version of blended learning and enables the use of lesson time more effectively and efficiently compared to traditional classrooms (Ucar \& Bozkurt, 2018). It is quite similar to blended learning as it also consists of face-to-face and online learning, yet it is different in the way that outside activities utilized in flipped classroom can either be online or include paper and hard copy materials, which means that videos are not obligatory in flipped classrooms and the use of instructional videos does not necessarily indicate flipping a classroom (Alsowat, 2016).

The flipped classroom was called inverted classroom in the late 1900s and early 2000s, replaced what was traditionally done in the classroom with what was done at home (Lage, Platt, \& Treglia, 2000; Bergmann \& 
Sams, 2012). One of the most extensive definitions of the flipped classroom is that students are prepared for face-to-face time via reading and watching materials before the in-class time in order to be able to use that knowledge they have gained from the materials for activities instead of explicit instruction (Quint, 2015). Emerging developments in computers and software has made it easier for instructors to record, annotate, and post video lessons online and they can carry out these tasks without needing any formal professional development or training (Wang \& Reeves, 2003), and also it is quite easy and inexpensive. The videos prepared by the instructors are mostly 10-15 minutes in length and consist of images, narration, video and interactive components (Wiginton, 2013). The content provided in the video is actually the same with what they would learn in a traditional lecture classroom. Additionally, recent technologies enabled students to access the videos prepared by the instructors easily by clicking a link on a learning management system used by the school or watch them from social media websites such as YouTube (Wiginton, 2013). For instance, Bergmann and Sams (2012) created their videos by utilizing screen-capture software and shared it with their students online or in a downloadable format for their mobile devices. As the students born in the 21 st are already competent in the digital world (Barone, 2003), the use of videos prepared by the course instructor is not even crucial (Kenna, 2014) as they can also autonomously find videos and information on websites such as Google ${ }^{\oplus}$, YouTube Wikipedia ${ }^{\oplus}$ (Carlisle, 2010), Khan Academy, and Ted (Tucker, 2012) themselves. Flipped classroom approach brings along various benefits. One of them is that students learn the topic at their own pace as they are able to pause and rewind the lecture videos, meanwhile search for information related to unclear and confusing parts, and gain the basic necessary fundamental knowledge about the topic to be covered in the class time (Bergmann \& Sams, 2012). Additionally, the videos can be viewed by the students individual (Kenna, 2014), which promotes individualized learning. In return, it provides time for incorporating more active learning strategies into the class time (Gannod, 2007; Kellogg, 2009; Warter-Perez \& Dong, 2012). In this respect, Gannod, Burge, \& Helmick (2008) pointed out that the advantages of providing an online learning management system where students can access the lecture content and study it in their self-paced learning environment is that "the learner can access the information at their own pace and continually reference recorded material" (p. 779). However, in traditional classrooms, the subject is provided by the instructor in a lecture format. During the lecture, students are mostly passive learners and try to listen, take notes and learn at the same time. Additionally, courses taught via traditional methods require students to learn at the same pace with all students in the classroom regardless of their mastery (Wiginton, 2013). For some students, the topic covered in the lesson might be familiar, yet the other might have difficulty in taking in information so quickly or lack the background knowledge needed to understand the content presented (Goodwin \& Miller, 2013). Due to time constraint, the practices regarding the lecture are assigned as homework. Besides, as lecturing takes up most of the class time, usually, there is not much time left for the teacher to help each student in the classroom. The situation is the same at home as there is often no one to help students to do their homework at home, which leads students to feel frustrated and fail at completing or doing their homework properly. In the end, repeated incidents such as these often causes low self-efficacy and loss of enthusiasm and effort (Bandura, 1997). Considering the mentioned problems and necessities, the reviewed literature indicated that flipped classroom approach (FCA) would be quite effective in order to improve the writing skills of the learners.

A plethora of research has been carried out regarding the implementation and efficacy of flipped classroom approach regarding various sciences (Strayer, 2007; Johnson \& Renner, 2012; Szparagowski, 2014; Soliman, 2016). There is scarce research related to the implementation of flipped classroom approach in EFL education, yet there are some studies focusing on English instruction (Snowden, 2012; Baranovic, 2013; Hung, 2015; Webb \& Doman, 2016) most of which are conducted in higher education (Strayer, 2007; Pierce \& Fox, 2012; Ruddick, 2012; Zappe, Leicht, Messner, Litzinger Lee, 2009; Baranovic, 2013).

Ahmed (2016) for example, studied the perceptions of learners on the flipped classroom approach and its impact on their writing achievement at Qassim University. The study aimed at investigating the impact of flipped classroom approach on writing skills in English a foreign language and the attitudes of learners towards the approach. The participants consisted of 60 students: 30 for control group and 30 for experimental group. The findings from an EFL writing text and a questionnaire measuring the attitudes of learners towards the flipped classroom approach and which were both applied twice as pre- and posttests revealed that the experimental group who were taught via the flipped classroom approach outperformed the control group in the post-test of EFL writing. Additionally, the findings of the questionnaires indicated that there was a statistically significant difference between the attitudes of learners in favor of the experimental group. 
In another study, Ekmekci (2017) studied the flipped writing classroom in Turkish EFL context. The study aimed at investigating the impact of flipped classroom approach on the foreign language writing skills of Turkish learners studying at a university. The study compared flipped and traditional face-to-face writing classes with regard to the writing performances of learners and applied a pre- and post-test true experimental design with a control group. The findings obtained from the pre- and posttests revealed that there was a statistically significant difference between the experimental and control groups regarding their writing performances. In other words, the learners in the flipped classroom outperformed the learners in the traditional classroom. Additionally, it was found out that most of the learners presented positive attitude towards Flipped Writing Model.

Another benefit of the flipped classroom is that students learn the topic at their own pace as they are able to pause and rewind the lecture videos, meanwhile search for information related to unclear and confusing parts, and gain the basic necessary fundamental knowledge about the topic to be covered in the class time (Bergmann \& Sams, 2012). Therefore, it can be stated that learners are expected to be self-regulated learners. Self-Regulated learning (SRL) has been defined by plenty of researchers in various ways. The term became popular in the 1980s due to the emphasis put on emerging autonomy and the responsibilities to be done by students for their own learning (Bandura, 1986). The two fundamental names studying SRL to a large extent were Zimmerman and Pintrich. Zimmerman (2000) defined SRL as generating thoughts, feelings and actions which are planned and cyclically arranged in order to meet personal goals. As for Pintrich (2000), SRL meant "an active, constructive process whereby learners set goals for their learning and then attempt to monitor, regulate, and control their cognition, motivation, and behavior, guided and constrained by their goals and the contextual features of the environment" (p.453). However, little research has been conducted regarding the integration of FCA and SRL and the impact of FCA on the SRL of students (Sun, Wu, \& Lee, 2017). Additionally, the findings of the relevant studies yielded inconsistent results (Cakiroglu \& Ozturk, 2017; Sun et al., 2017; Elakovich, 2018; El-Senousy \& Alquda, 2018).

Based on the reviewed literature and the requirements of learners and teachers, this study aims at exploring the impact of flipped classroom approach on the self-regulated learning and writing levels of pre-service English teachers. In the light of the above discussion, this study aims at investigating these research questions:

1. Is there any difference between the pre-service ELT teachers exposed to flipped classroom approach (experimental group, EG) and the ones engaged in traditional lecture-based instruction (control group, CG) in terms of their self-regulated learning?

2. Is there any difference between CG and EG in terms of their L2 Advanced Writing achievement after the implementation of FCA?

\section{THEORETICAL FRAMEWORK OF THE STUDY}

The flipped classroom differs from the traditional classroom in which the teacher provides lecture about the new topic in class and then have students comprehend their knowledge via doing assignments (Brame, 2013). In this study, FCA was implemented in an Advanced Writing course and the course was designed in accordance with Bloom's Taxonomy. The new version of Bloom's Taxonomy developed by Anderson et al (2001) is as following:

1. remembering - retrieving, recognizing, and recalling relevant knowledge from long-term memory;

2. understanding - constructing meaning from oral, written, and graphic messages through interpreting, exemplifying, classifying, summarizing, inferring, comparing, and explaining;

3. applying - carrying out or using a procedure through executing, or implementing; analyzing - breaking material into constituent parts, determining how the parts relate to one another and to an overall structure or purpose through differentiating, organizing, and attributing;

4. evaluating - making judgments based on criteria and standards through checking and critiquing; creating - putting elements together to form a coherent or functional whole;

5. reorganizing elements into a new pattern or structure through generating, planning, or producing ( $\mathrm{p}$. 67-68). 
It is stated that applying Bloom's revised taxonomy to a flipped course increases students' learning outcomes, enables student-paced lectures, more personalized learning (Srivastava, 2014), and as passive learning (remembering and understanding) is covered through students' studying the fundamental course material provided with video lectures prior to class, students are more prepared to apply the knowledge and participate in higher-level discussions with their peers and the course instructor, which also enables them to have the support of their peers and the course instructor (Brame, 2013). In this respect, students are expected to be able to manage their own learning process, be self-regulated learners and active in the lesson.

Self-Regulated learning (SRL) has been defined by plenty of researchers in various ways. The term became popular in the 1980s due to the emphasis put on emerging autonomy and the responsibilities to be done by students for their own learning (Bandura, 1986). The two fundamental names studying SRL to a large extent were Zimmerman and Pintrich. Zimmerman (2000) defined SRL as generating thoughts, feelings and actions which are planned and cyclically arranged in order to meet personal goals. As for Pintrich (2000), SRL meant "an active, constructive process whereby learners set goals for their learning and then attempt to monitor, regulate, and control their cognition, motivation, and behavior, guided and constrained by their goals and the contextual features of the environment" (p.453). Furthermore, Hadwin (2008) described it as "deliberate planning, monitoring, and regulating of cognitive, behavioral, and affective or motivational processes toward completion of an academic task" (p.187).

Although flipped classroom approach is not a newly found concept, there is little research investigating the effect of self-regulated learning on the learners even though it is claimed to increase the motivation and self-efficacy of learners. The studies conducted mostly focus on the relationship between SRL and online learning environments. Compared to the traditional lecture classroom where there is a passive learning environment the self-directed online learning environment is claimed to foster self-regulation (Barak, 2009). Self-Regulated learning (SRL) has been defined by plenty of researchers in various ways. The term became popular in the 1980s due to the emphasis put on emerging autonomy and the responsibilities to be done by students for their own learning (Bandura, 1986). The two fundamental names studying SRL to a large extent were Zimmerman and Pintrich. Zimmerman (2000) defined SRL as generating thoughts, feelings and actions which are planned and cyclically arranged in order to meet personal goals. As for Pintrich (2000), SRL meant "an active, constructive process whereby learners set goals for their learning and then attempt to monitor, regulate, and control their cognition, motivation, and behavior, guided and constrained by their goals and the contextual features of the environment" (p.453). Furthermore, Hadwin (2008) described it as "deliberate planning, monitoring, and regulating of cognitive, behavioral, and affective or motivational processes toward completion of an academic task" (p.187).

Despite the diverse perceptions of researchers regarding the explanations of SRL, the theories rely on three common features. First, SRL requires deliberate use of particular processes, strategies or replies, by students in order to develop their academic success (Zimmerman, 2001). In other words, students are expected to be aware of the potential benefits of self-regulation processes in improving their academic success (Abd Majid, 2007). Secondly, as the practice of SRL involves the need for self-oriented feedback (Abd Majid, 2007), SRL involves a cyclical process of feedback in which students participate in observing how effective the strategies they use while learning are and the various ways they respond to feedback (Almazloum, 2018). These strategies include time, the study environment, the place where they study, and asking for help from peers and teachers. Thirdly, self-regulation of motivation for selecting certain SRL strategies and the rationale behind the choice of students is a common feature of SRL (Almazloum, 2018). Additionally, Zimmerman (2001) stated that it is necessary for students to have extra time to prepare, to participate in tasks, and they need struggle with adequately satisfying outcomes in order to self-regulate their learning process.

Flipped classroom is stated to be quite beneficial (Kellogg, 2009; Warter-Perez \& Dong, 2012); however, little research has been conducted regarding the integration of FCA and SRL and the impact of FCA on the SRL of students (Sun, Wu, \& Lee, 2017). Additionally, flipped classrooms are regarded as more self-centred as students practice autonomy and manage their own responsibilities, especially in asynchronous learning environments (Artino, 2008). It was also claimed that as self-regulated learners are efficient in time and space management, observing their learning process and analyzing their own curricular or extracurricular learning outputs, enhancing their engagement in the class via discussion, analysis, synthesis, and problem solution, FCA model can be used profoundly in these contexts (Cigdem, Ozturk, \& Topcu, 2016). In parallel with this 
statement, it was also claimed that via forming the temporal "space" for metacognition FCA could improve self-efficacy and motivation (Hewitt et al., 2014) and that the temporal space provided by the flipped video content urges learners to reflect on and self-evaluate their learning process, which can be interpreted as FCA supplies an environment useful for metacognition, a fundamental component of SRL (Zimmerman, 1990). In fact, Strayer (2012) deduced that learners in a flipped classroom become more conscious about their own learning process compared to learners in a traditional lecture classroom.

Control over learning is a requirement of SRL (Bergamin, et al., 2012). In this respect, it was pointed out that students consider the control over learning that occurs due to the flexibility provided by FCA quite beneficial (Cole \& Kritzer, 2009; Hewitt et al., 2014). In addition, FCA is claimed to increase student motivation (Hewitt et al., 2014), which is a crucial element of SRL, (Zimmerman, 1990) and their self-confidence. Selfconfident students are also expected to have stronger self-efficacy perceptions, which promotes motivation in turn and perhaps the most significant factor ensuring valuable outputs (Nodoushan, 2012).

As for the perceptions of students, it was found out that students preferred implementing SRL strategies in online learning environments compared to the traditional learning setting (Lee \& Tsai, 2011). In this respect, Liaw and Huang (2013) investigated how satisfied students were regarding online learning contexts (i.e. acceptance of system and feeling of comfort utilizing system) and how it affected SRL. The findings revealed that SRL in online contexts was perceived as satisfying by learners; in other words, the attitudes of students about online settings had an impact on their learning behaviours.

In this respect, it can be concluded that applying Bloom's taxonomy to a flipped course is expected to increase self-regulated learning of students as passive learning (remembering and understanding) is provided through video lectures and students are able to acquire the knowledge by watching the videos at their own pace, as many times they need or want. Furthermore, FCA enhances active learning stages of Bloom's taxonomy (applying, evaluating, reorganizing) as students are required to participate in higher-order thinking tasks such as analysis, synthesis, evaluation, and reflection through various activities done in the classroom (Tabrizi \& Rideout, 2017).

In this course, the lower-order thinking skills, which also comprise passive learning stages (remembering and understanding) of Bloom's taxonomy, are provided via video lectures that students watch prior to class (Sams \& Bergmann, 2013). In other words, remembering and understanding skills are completed out of the classroom without teacher supervision, and students can watch the video lectures at their own pace and as many times as they want or need to remember information and understand the concepts (Eppard $\&$ Rochdi, 2017). As for analyzing and applying skills, the students apply the information and concepts by working collaboratively with their peers or with the help of their teacher. Lastly, for evaluating and creating, the higher order thinking skills, students can still work collaboratively, yet they are expected to complete the tasks individually and accurately in the end (Eppard \& Rochdi, 2017). Therefore, the video lectures which consisted of explanations related to essay writing rules and strategies corresponded to the lower-order thinking skills, and the higher-order thinking skills (applying, analyzing, evaluating, creating) were carried out in the classroom through pair work, discussions, group work, exercises, writing essays, etc.

In this study, flipped advanced writing course aims at teaching pre-service English teachers to learn fundamental essay writing rules through video lectures. Additionally, it aims at enabling participants to engage in higher-level discussions, write meaningful and accurate essays in a structured way by using the knowledge they have gained, participate in classroom discussions, and get assistance from their peers and the course instructor in the classroom. In this respect, considering the aims of the course, Bloom's taxonomy integrated flipped classroom approach was preferred for the design of the course.

\section{METHOD}

This study adopted a pretest-posttest quasi-experimental design. As the participants were purposefully chosen, quasi-experimental research was chosen. According to Johnson and Christensen (2004) the aim of a quasi-experimental research design is to discover whether an intervention has the expected impact on a study's participants. 


\section{Participants}

The participants of this study consisted of fifty-five (N=55) pre-service ELT teachers attending Advanced Writing course and studying at English Language Teaching Department (ELT) at a foundation (non-profit, private) university in the fall semester of 2017-2018 academic year. Advanced Writing course is a compulsory course required by the Council of Higher Education for English Language Teaching departments. The course consists of four hours in total (two hours theory, two hours practice) per week and lasts 14 weeks in both fall and spring terms. This course aims at providing students with the fundamental writing skills they need to undertake academic work at a university successfully.

The first day of the first week, the instructor asked all the students to attend the class on Monday and announced them that the course will be run on two days: Monday and Friday, and that the students were going to be randomly divided into two groups, experimental (EG) vs control (CG). The group on Monday was identified as the CG and the one on Friday as the EG. Simple random sampling was preferred in order to provide each participant equal chance to be in the classroom where a new approach would be carried out. Furthermore, the instructor of the study also participated by reflecting on the process, her teaching and application of the flipped classroom approach. Whereas, the EG was expected to watch the videos uploaded on ItsLearning every Tuesday morning before coming to the classroom on Friday and the CG was expected to do their homework before coming to the classroom on Monday. For the CG, the instructor focused on providing the content and doing as much practice as she could in the classroom and the practice left was given as assignment. As for the EG, the instructor focused on doing the practice, guiding learners, and facilitating collaborative work in the classroom. Demographic characteristics of the participants are given in Table 1:

Table 1. Distribution of participants regarding their age, gender and educational background

\begin{tabular}{|c|c|c|}
\hline \multicolumn{3}{|c|}{ Overall } \\
\hline Gender & $\mathrm{N}$ & $\%$ \\
\hline Female & 40 & 73 \\
\hline Male & 15 & 27 \\
\hline Total & 55 & 100 \\
\hline \multicolumn{3}{|l|}{ Age } \\
\hline 18 & 14 & 25 \\
\hline 19 & 22 & 40 \\
\hline 20 & 12 & 22 \\
\hline 21 & 5 & 9 \\
\hline 22 & 2 & 4 \\
\hline \multicolumn{3}{|l|}{ Educational Background } \\
\hline Attended Prep. Class & 28 & 51 \\
\hline Did Not Attend Prep Class & 27 & 49 \\
\hline Total & 55 & 100 \\
\hline State Primary School & 43 & 78 \\
\hline Private Primary School & 12 & 22 \\
\hline Total & 55 & 100 \\
\hline State Secondary School & 34 & 62 \\
\hline Private Secondary School & 21 & 38 \\
\hline Total & 55 & 100 \\
\hline State High School & 32 & 58 \\
\hline Private High School & 23 & 42 \\
\hline Total & 55 & 100 \\
\hline
\end{tabular}




\section{Data Collection and Analysis}

In order to gather the necessary data for the study, two quantitative data collection instruments were utilized: Self-Regulated Learning Scale adopted from the study of Erdogan and Senemoglu (2016) and writing preand post-tests.

As one of the aims of this study was to find out whether the application of flipped classroom approach had any effect on the self-regulated learning levels of the participants, self-regulation in learning (SSRL) was conducted. The scale was adopted from the study carried out by Erdogan \& Senemoglu (2016) and it aimed at developing and validating a scale on self-regulation in learning. This scale was preferred due to its convenience for university level students and its detailed items questioning self-regulated learning and considering it from various angles. The scale consisted of two main parts: self-regulated learning skills/ strategies and motivational dimension. The first part included 3 subheadings, which are before study, during study and after study. In the "before study part" goal setting and planning, and environmental structuring skills were investigated. As for the "during study part", the items studied organization and transforming, seeking information, rehearsing and memorizing, keeping record and self-monitoring, seeking peer, teacher or adult assistance, and reviewing skills. Lastly, "after study part" questioned self-evaluation and selfconsequences skills. Additionally, motivational dimensions of the scale consisted of five subheadings, which are self-efficacy, goal-orientations, task value, attributions for failure, and anxiety. The questionnaire consisted of 67 questions with 5-point Likert-type response format. The participants were asked to evaluate themselves between (1) corresponds exactly and (5) does not correspond at all. The questionnaire was administered to the students as pre-test in the second week of the term and as post-test at the end of the term. The questionnaire was pilot tested in the first week of the term with 10 students in order to measure the reliability of the questionnaire items. Cronbach's alpha coefficiency test was conducted and it was measured .881 . Therefore, it can be concluded that the items were statistically reliable to be administered to pre-service ELT teachers (Ary, Jacobs, Sorenson, \& Walker, 2013).

This study aimed at investigating the impact of FCA on the writing achievements of the participants. Therefore, two different writing exams were conducted. The first one, the pre-test, was conducted in the first week of 2017-2018 academic year spring term, and the post test was administered in the last week of the spring term. Both exams were prepared by the instructor and the researcher following the objectives of the course and the materials used in the lesson. Although the essay types and topics of the exams differ, both writing parts required being able to follow the rules of writing a proper and meaningful essay and apply the correct structure in accordance with the type of the essay. The writing part included a few topics and the students were asked to choose one of the topics provided and write an essay based on the type they are asked to and in both exams, the writing sections were graded out of 50 .

The treatment process started in the spring term. The participants were divided into two groups: Experimental Group (EG) and Control group (CG). The EG were taught via Flipped Classroom Approach, which meant watching the video lessons prepared shared and reading the articles or texts if shared any by the instructor before coming to the lesson each week. The students were supposed to follow ItsLearning regularly as the video lessons, texts and announcements were shared via this learning management system. The instructor and the researcher worked together each week in order to prepare the PowerPoint providing the lecture content each week. Additionally, they prepared the questions that they would embed in the video via using EdPuzzle. The instructor recorded the screen of her laptop while narrating the PowerPoint via Camtasia, uploaded the video to EdPuzzle and embedded the questions in the video, and finally shared it on ItsLearning 5-6 days before the lesson each week. All the participants were required to watch the videos regularly prior to class in order to come to the class having acquired the knowledge. Therefore, as the researcher and the course instructor aimed at increasing the video viewing rates of the participants, they checked the data obtained through EdPuzzle at the end of the term. The analysis of the data obtained from EdPuzzle yielded that 85\% of the pre-service English teachers watched the videos. As for the in-class practice, the exercises of each topic were covered during the in-class hours in the classroom. During this whole process, implementing the stages of Bloom's Taxonomy was cared. As for the CG, the lecture was provided in the classroom and the instructor did as much practice as she could during the lesson hour and the rest was given as homework to the students. Especially, essay writing parts were not covered in the classroom due to time constraints and students wrote their essays at home as homework. 
In the treatment process, firstly, to measure the impact of FCA on students' Advanced Writing skills, the writing exam was conducted in the first week of the second term as pre-test. Additionally, in the first week of the term, the researcher pilot tested the self-regulated learning scale with $10(\mathrm{~N}=10)$ randomly selected students from both groups in order to ensure the reliability of the items. Cronbach's alpha coefficiency test results with a .881 score indicated that the items were reliable. Therefore, the scale was administered in the second week to the participants as pre-test. The scale was transferred to google forms and the shareable link was uploaded to ItsLearning, and the participants were asked to complete it until the next lesson. In the last week, the participants were asked to complete the self-regulated learning scale again as post-test. The questionnaire was prepared via google forms and the link was shared on ItsLearning. The instructor asked the students to fill in the questionnaire until final exam. And lastly, in the last week, the final writing exam was administered as post-test.

As for the data analysis, in this study, the quantitative data which were collected via Advanced Writing test scores, and Self-Regulated Learning scale were analyzed by means of SPSS 23 (Statistics Package for Social Sciences) data analysis program. In order to determine the significance level of pre-tests and post-tests, ANOVA was utilized to analyze whether there was statistically significant difference regarding the data. The significance level was accepted as $\mathrm{p}<0.05$ in this study and comments and discussions on the findings of the study were carried out based on this significance level. In order to analyze quantitative data, descriptive statistics were conducted using SPSS 23 (Statistical Package for the Social Sciences) and ANOVA was applied to compare pre-post advanced writing exam scores and self-regulated learning scores between and within groups. The level of significance for the statistical analyses was accepted as .05.

\section{The Scale}

In order to conduct a study with reliable findings, ensuring reliability and validity are fundamentally significant for a researcher (Ary et al., 2010). Creswell (2012) defined validity as "the development of sound evidences to demonstrate that the test interpretation of (scores about the concept or construct that the test is assumed to measure) matches its proposed use" (p.159).

In the present study, the data collection instruments were the self-regulated learning scale and the advanced writing pre- and post-tests. First of all, the writing part was evaluated based on a rubric and answer key prepared by the instructor and was graded by the researcher and the instructor of the course. The average score coming from both raters were accepted as the grade, which enabled more reliable interpretation. When reliability is concerned, "the effect of error on the consistency of scores" was taken into consideration (Ary et al., 2010, p. 237). The main issues leading to scoring reliability concerns are random errors, which are the results of "the individual being measured, the administration of the measuring instrument, and the instrument" (p. 237). As the tests were conducted and scored by the same instructor and the researcher, it can be put forward that administration of measuring the instrument did not lead to any error. Furthermore, the exams were shown to two other instructors who run this course in the previous years in order to contribute to the face validity of the questions. As for the self-regulated learning scale, a pilot study was conducted for each before the treatment to check their reliability scores, which were found to be .884 and .881 respectively and were high enough to consider them as reliable tools (Gliem \& Gliem, 2003).

Validity needs to be supported with reliability which is an indicator of how stable and consistent the data collection tools are. Mertler and Charles (2005) stated that there were two sides of experimental validity: internal and external validity. Internal validity indicates to what extent a study can make inferences about the causal relationship between dependent and independent variables. Additionally, Jiménez-Buedo \& Miller (2010) stated that "if an experiment is not internally valid, then, we cannot say that the treatment given in the experiment is the cause of the effect we observe" (p. 301). The major threats to internal validity are history, testing, maturation, selection bias and unstable instrumentation (Mertler \& Charles, 2005). In this study, in order to eliminate the history effect, the pre-post tests were administered to both groups simultaneously. Additionally, testing effect was defined as the effect of pre-test results on the post-test results (Jha, 2014), which increases due to the time interval between the pre and posttests. Additionally, the risk of testing effect has been taken into consideration as there was a 12-week interval between the utilization of pre-tests and post-tests. Most importantly, the essay types asked in the pre-test and post-test were utterly 
different from each other as the writing achievements of the learners were assessed before and after the treatment. As for the risk of maturation effect, since the students were between 17-22 years old and were all university students at a private university, it was at minimum level. Lastly, the levels of the experimental and control groups were almost equal, which also assisted in establishing a high external validity in this study. However, the sample size being quite small has an impact on the external validity, which makes it hard for the results of the study to be generalized.

\section{Significance and Limitations}

Although the use of technology in the classrooms has increased in recent years, many instructors tend to integrate technology into their teaching without truly understanding the effect of it, the need for it and failing to consider whether it will meet the needs of the students and the course and have a positive impact on the attitudes, level of achievement and learning experience of the learners.

Considering the tendency to integrate technology into teaching, research on flipped classroom approach has gained significance in recent years. However, it was noticed that the results does not show a consistent increase in student academic growth. While some studies have indicated that computer-assisted instruction leads to academic growth (Engin \& Donanci, 2014; Farah, 2014; Ahmed, 2016) the research exploring the academic growth of students provided with flipped teaching strategy has shown inconsistent results (Finkel, 2012; Heredia, 2015; Cashin, 2016). Additionally, studies on the effect of flipped teaching strategy are scarce (Findlay-Thompson \& Mombourquette, 2014), especially in the field of English language teaching at undergraduate levels. However, the majority of recent studies focusing on the effect of flipped teaching strategy with regard to the writing performance of students are in favor of flipped teaching strategy and attribute the increase of the achievement scores to flipped classroom approach when compared to traditional lecture-based teaching strategy (Baranovic, 2013; Farah 2014; Leis, Cooke, \& Tohei, 2015; Ekmekci, 2014).

This study will offer a new perspective by expanding the conducted studies on the use of flipped classroom approach in order to improve the advanced writing performance and self-regulated learning levels of pre-service ELT teachers provided within Turkish setting. Furthermore, this study will contribute to the implementation of flipped teaching strategy in foreign language schools, undergraduate and graduate level schools. Lastly, it will be guidance to the teachers, administrators and schools willing to apply flipped classroom approach in their classrooms and schools.

Although the study has achieved its objectives thanks to detailed and thorough data collection and analysis procedure, some limitations with regard to its implementation should also be considered. Firstly, the amount of data was sometimes insufficient to reach concrete arguments. For instance, the test data collected to compare the EG and CG in terms of their advanced writing achievement scores could have been supported with their portfolio grades, yet some of the pre-service teachers in the CG did not submit their essays, the researcher lacked the data necessary to make a proper comparison. In that case, the study could provide more comprehensive results. To prevent this case, pre-service teachers might have been informed about the significance of their portfolios in terms of their grading process and warned to bring them on time. Moreover, the number of participants was small $(N=55)$. With a larger number of participants, a higher external validity and more reliable results could be ensured and the study could be more generalizable. Additionally, the study was conducted with only pre-service ELT teachers in a foundation university and examined one course only. The results might show difference if the study is applied in another university, specifically a state university or in higher grades or if the flipped classroom approach was implemented in another course, which would also increase the external validity of the study. Lastly, some of the participants in the control group might have had the chance to access the videos and watch them, which might have a negative impact on the comparative analysis of the study. Therefore, the findings of this study should be considered as suggestive rather than conclusive, and attempts should be made to replicate and expand these findings into further research in the field. 


\section{FINDINGS}

This chapter presents the findings of this study which aimed at investigating the effect of FCA on the writing levels, self-regulated learning levels of pre-service English teachers. The following sections will provide the detailed results of quantitative data respectively.

\section{Finding about Detailed Writing Scores}

The following section demonstrates advanced writing achievement of the control and experimental groups. A comparative analysis was made and the between-group statistics were displayed to discover whether there was a difference between the writing achievement scores of the groups due to the different teaching methods: traditional and flipped.

According to the rubric, the essays of the learners were analyzed regarding six main categories: 1) Introduction \& Thesis Statement, 2) The Body, 3) Conclusion, 4) Coherence \& Cohesion, 5) Vocabulary, and 6) Mechanics and Use of English (punctuation, spelling, capitalization, grammar). The learners who fulfilled the necessities of each category well received max 9 points for the first three categories, and max 8 points for the 4th and 5th categories, and lastly max 7 points in the 6th category, which in total made 50 if a learner fulfilled all the requirements of a well-organized essay based on the rubric.

Table 2 displays that there is statistically significant difference between the groups with regard to the pre and post-tests of the writing part in the exams $\left(\mathrm{p}=0.05, \eta_{\mathrm{p}}{ }^{2}=.071\right)$. Therefore, it can be stated that flipped classroom had a positive impact on the writing achievement of the experimental group. Additionally, based on the findings, it could be interpreted that both groups made progress in the post-test (CG: $M=35.74, S D=13.84$ / EG: $M=40.53, S D=8.75)$ compared to the pre-test (CG: $M=34.07, S D=9.71 / E G: M=37.96, S D=9.07)$.

Table 2. Comparison of writing achievement with mixed ANOVA

\begin{tabular}{ccccccc}
\hline Source & $\begin{array}{c}\text { Type III Sum } \\
\text { of Squares }\end{array}$ & df & $\begin{array}{c}\text { Mean } \\
\text { Square }\end{array}$ & $F$ & Sig. & Partial Eta Squared \\
\hline $\begin{array}{c}\text { Between } \\
\text { Groups }\end{array}$ & & & & & & .071 \\
\hline $\begin{array}{c}\text { Group (CG/ } \\
\text { EG) }\end{array}$ & 518.427 & 1 & 518.427 & 4.033 & $.050^{*}$ & \\
\hline Error & 6812.537 & 53 & 128.538 & & \\
\hline
\end{tabular}

Note. ${ }^{*} p<.05,{ }^{* *} p<.01$

Furthermore, table 3 displays that there is statistically significant difference between the groups with regard to the pre (CG: $M=6.07, S D=1.96 / E G: M=6.82, S D=2.03)$ and post-test scores (CG: $M=5.40, S D=2.20$ / EG: $M=7.14, S D=1.93)$ of the introduction part in the exams $\left(p=0.005<0.05, \eta_{p}{ }^{2}=.108\right)$. Therefore, it can be stated that flipped classroom had a positive impact on the writing achievement of the experimental group.

Table 3. Comparison of introduction part writing achievement with mixed ANOVA

\begin{tabular}{ccccccc}
\hline Source & $\begin{array}{l}\text { Type III } \\
\text { Sum of } \\
\text { Squares }\end{array}$ & df & $\begin{array}{c}\text { Mean } \\
\text { Square }\end{array}$ & $F$ & Sig. & Partial Eta Squared \\
\hline $\begin{array}{c}\text { Between } \\
\text { Groups }\end{array}$ & & & & & & $.005^{*}$ \\
\hline $\begin{array}{c}\text { Group (CG/ } \\
\text { EG) }\end{array}$ & 42.366 & 1 & 42.366 & 8.510 & & \\
\hline Error & 263.853 & 53 & 4.978 & & & \\
\hline
\end{tabular}

Note. ${ }^{*} p<.05,{ }^{* *} p<.01$ 
As for the body part of the participants' essays, table 4 presents that there is statistically significant difference between the groups with regard to the pre (CG: $M=5.92, S D=2.14$ / EG: $M=6.78, S D=2.18$ ) and post-tests scores (CG: $M=5.92, S D=2.36$ / $E G: M=7.10, S D=1.37)$ of the body parts in the exams $(p=0.019<0.05$, $\eta_{\mathrm{p}}{ }^{2}=.080$ ), which can be interpreted as the positive impact of FCA on the writing achievement of the experimental group.

Table 4. Comparison of body part writing achievement with mixed ANOVA

\begin{tabular}{ccccccc}
\hline Source & $\begin{array}{l}\text { Type III } \\
\text { Sum of } \\
\text { Squares }\end{array}$ & df & $\begin{array}{c}\text { Mean } \\
\text { Square }\end{array}$ & $F$ & Sig. & Partial Eta Squared \\
\hline $\begin{array}{c}\text { Between } \\
\text { Groups }\end{array}$ & & & & & $.019^{*}$ & .080 \\
\hline $\begin{array}{c}\text { Group (CG/ } \\
\text { EG) }\end{array}$ & 28.630 & 1 & 28.630 & 5.858 & \\
\hline Error & 259.043 & 53 & 4.888 & & \\
\hline
\end{tabular}

Note. ${ }^{*} p<.05,{ }^{* *} p<.01$

According to table 5, it can be stated that there is statistically significant difference between the groups with regard to the pre (CG: $\mathrm{M}=5.92, \mathrm{SD}=1.96$ / $\mathrm{EG}: \mathrm{M}=6.53, \mathrm{SD}=1.97)$ and post-test scores (CG: $\mathrm{M}=5.96$, $\mathrm{SD}=2.32$ / $\mathrm{EG}: \mathrm{M}=7.10, \mathrm{SD}=1.31)$ of the conclusion part in the exams $\left(\mathrm{p}=0.029<0.05, \eta_{\mathrm{p}}{ }^{2}=.070\right)$, which can indicate that FCA has a positive impact on the writing achievement of the experimental group.

Table 5. Comparison of conclusion part writing achievement with mixed ANOVA

\begin{tabular}{ccccccc}
\hline Source & $\begin{array}{l}\text { Type III } \\
\text { Sum of } \\
\text { Squares }\end{array}$ & $\mathrm{df}$ & $\begin{array}{c}\text { Mean } \\
\text { Square }\end{array}$ & $\mathrm{F}$ & Sig. & Partial Eta Squared \\
\hline $\begin{array}{c}\text { Between } \\
\text { Groups }\end{array}$ & & & & & & .070 \\
\hline $\begin{array}{c}\text { Group (CG/ } \\
\text { EG) }\end{array}$ & 21.143 & 1 & 21.143 & 5.013 & $.029^{*}$ & \\
\hline Error & 223.548 & 53 & 4.218 & & & \\
\hline
\end{tabular}

Note. ${ }^{*} p<.05,{ }^{* *} p<.01$

When the coherence and cohesion of the participants' essays analyzed and compared between groups and within groups, the results presented in table 6 revealed that there is statistically significant difference between the scores of the coherence and cohesion pre-test (CG: $\mathrm{M}=5.40, \mathrm{SD}=1.62$ / $\mathrm{EG}: \mathrm{M}=5.96, \mathrm{SD}=1.73$ ) and post-test scores (CG: $\mathrm{M}=6.00, \mathrm{SD}=2.40 / \mathrm{EG}: \mathrm{M}=7.35, \mathrm{SD}=1.68)$ of the groups $\left(\mathrm{p}<.05, \eta_{\mathrm{p}}{ }^{2}=.077\right)$.

Table 6. Comparison of coherence \& cohesion-writing achievement with mixed ANOVA

\begin{tabular}{ccccccc}
\hline Source & $\begin{array}{l}\text { Type III } \\
\text { Sum of } \\
\text { Squares }\end{array}$ & $\mathrm{df}$ & $\begin{array}{c}\text { Mean } \\
\text { Square }\end{array}$ & $\mathrm{F}$ & Sig. & Partial Eta Squared \\
\hline $\begin{array}{c}\text { Between } \\
\text { Groups }\end{array}$ & & & & & .077 \\
\hline $\begin{array}{c}\text { Group } \\
(\mathrm{CG} / \mathrm{EG})\end{array}$ & 25.178 & 1 & 25.178 & 5.013 & $.029^{*}$ & \\
\hline Error & 230.313 & 53 & 4.346 & & \\
\hline
\end{tabular}

Note. ${ }^{*} p<.05,{ }^{* *} p<.01$ 
As for the vocabulary progress of the groups, table 7 demonstrates that there is statistically significant difference between the groups based on the comparison of their vocabulary scores in the pre-test (CG: $\mathrm{M}=5.66, \mathrm{SD}=1.38$ / $\mathrm{EG}: \mathrm{M}=6.10, \mathrm{SD}=1.59)$ and post-test (CG: $\mathrm{M}=5.77, \mathrm{SD}: 2.17$ / $\mathrm{EG}: \mathrm{M}=6.85, \mathrm{SD}=$ $1.53)$ scores of the groups $\left(\mathrm{p}=0.04<0.05, \eta_{\mathrm{p}}{ }^{2}=.073\right)$. These findings could be interpreted as the positive effect of FCA on the vocabulary progress of the experimental group.

Table 7. Comparison of vocabulary-writing achievement with mixed ANOVA

\begin{tabular}{ccccccc}
\hline Source & $\begin{array}{l}\text { Type III } \\
\text { Sum of } \\
\text { Squares }\end{array}$ & $\mathrm{df}$ & $\begin{array}{c}\text { Mean } \\
\text { Square }\end{array}$ & $\mathrm{F}$ & Sig. & Partial Eta Squared \\
\hline $\begin{array}{c}\text { Between } \\
\text { Groups }\end{array}$ & & & & & & .073 \\
\hline $\begin{array}{c}\text { Group (CG/ } \\
\text { EG) }\end{array}$ & 15.875 & 1 & 15.875 & 4.364 & $.042^{*}$ & \\
\hline Error & 192.815 & 53 & 3.638 & & & \\
\hline
\end{tabular}

Note. ${ }^{*} p<.05,{ }^{* *} p<.01$

Lastly, table 8 displays that there is statistically no significant difference between the groups with regard to their correct use of English and mechanics considering their pre (CG: $M=5.63, S D=1.04$ / EG: $M=5.21$, $\mathrm{SD}=1.19)$ and post-tests (CG: $\mathrm{M}=5.37, \mathrm{SD}=1.98 / \mathrm{EG}: \mathrm{M}=6.57, \mathrm{SD}=1.45)\left(\mathrm{p}=0.183>0.05, \eta_{\mathrm{p}}{ }^{2}=.076\right)$, which can be interpreted as FCA has equal impact on the use of English, and mechanic progress of students as traditional lecture instruction.

Table 8. Comparison of mechanics and use of English achievement with mixed ANOVA

\begin{tabular}{ccccccc}
\hline Source & $\begin{array}{l}\text { Type III } \\
\text { Sum of } \\
\text { Squares }\end{array}$ & df & $\begin{array}{c}\text { Mean } \\
\text { Square }\end{array}$ & $F$ & Sig. & Partial Eta Squared \\
\hline $\begin{array}{c}\text { Between } \\
\text { Groups }\end{array}$ & & & & & .183 & .076 \\
\hline $\begin{array}{c}\text { Group (CG/ } \\
\text { EG) }\end{array}$ & 4.243 & 1 & 4.243 & 1.823 & \\
\hline Error & 123.357 & 53 & 2.327 & & \\
\hline
\end{tabular}

Note. ${ }^{*} p<.05,{ }^{* *} p<.01$

\section{Findings about the Influence of FCA on Self-Regulated Learning Levels}

To investigate the impact FCA on the self-regulated learning levels of the experimental group, to find out if there will be statistically significant difference between the pre-test and post-test scores of the control and experimental group after the treatment, a self-regulated learning scale (Erdogan \& Senemoglu, 2016) was applied as pre-test in the second week of the term, and post-test in the final week of the term.

The scale consists of 2 main parts: Self-Regulated learning skills and Motivational Factors. Additionally, selfregulated learning consists of 3 parts which are before, during and after study. Furthermore, before study part includes goal setting, planning, and environmental structuring subheadings, whereas during study part involves organization and transforming, seeking information, rehearsing and memorizing, keeping records and self-monitoring, seeking peer, teacher and adult assistance, and reviewing subheadings. Lastly, after study part consists of self-evaluation and self-consequences subheadings. As for the motivational factors, self-efficacy, goal orientations, task value, attributions for failure and anxiety are the subheadings.

A comparative analysis was made and the between-group statistics were displayed to discover whether there was a difference between the self-regulated learning levels of the groups due to the different teaching methods: traditional and flipped. 
Table 9. Comparison of overall self-regulated learning scores with mixed ANOVA

\begin{tabular}{ccccccc}
\hline Source & $\begin{array}{l}\text { Type III } \\
\text { Sum of } \\
\text { Squares }\end{array}$ & $\mathrm{df}$ & $\begin{array}{c}\text { Mean } \\
\text { Square }\end{array}$ & $\mathrm{F}$ & Sig. & Partial Eta Squared \\
\hline $\begin{array}{c}\text { Between } \\
\text { Groups }\end{array}$ & & & & & & .023 \\
\hline $\begin{array}{c}\text { Group (CG/ } \\
\text { EG) }\end{array}$ & .214 & 1 & .214 & 1.127 & .294 & \\
\hline Error & 9.133 & 48 & .190 & & & \\
\hline
\end{tabular}

Note. ${ }^{*} p<.05,{ }^{* *} p<.01$

Table 9 presents that there was not statistically significant difference between the groups with regard to their pre and post-tests of self-regulated learning levels $\left(\mathrm{p}=0.294>0.5, \eta_{\mathrm{p}}{ }^{2}=.023\right)$. Hence, it can be concluded that flipped classroom approach did not create any difference between the experimental and control groups' selfregulated learning pre-test (CG: $\mathrm{M}=3.29, \mathrm{SD}=0.38$ / $\mathrm{EG}: \mathrm{M}=3.31, \mathrm{SD}=0.40)$ and post-test (CG: $\mathrm{M}=3.29$, $\mathrm{SD}=0.38$ / EG: $\mathrm{M}=3.45, \mathrm{SD}=0.43)$ scores.

As for the first part of the scale, self-regulated learning skills, a comparative analysis was made and the between-group statistics were represented in table below.

Table 10. Comparison of self-regulated learning skills scores with mixed ANOVA

\begin{tabular}{ccccccc}
\hline Source & $\begin{array}{c}\text { Type III } \\
\text { Sum of } \\
\text { Squares }\end{array}$ & $\mathrm{df}$ & $\begin{array}{c}\text { Mean } \\
\text { Square }\end{array}$ & $\mathrm{F}$ & Sig. & Partial Eta Squared \\
\hline $\begin{array}{c}\text { Between } \\
\text { Groups }\end{array}$ & & & & & & .026 \\
\hline $\begin{array}{c}\text { Group (CG/ } \\
\text { EG) }\end{array}$ & .336 & 1 & .336 & 1.302 & .259 & \\
\hline Error & 12.392 & 48 & .258 & & \\
\hline
\end{tabular}

Note. ${ }^{*} p<.05,{ }^{* *} p<.01$

According to table 10 it can be inferred that there was statistically no significant difference between the groups with respect to their pre- (CG: $\mathrm{M}=3.20, \mathrm{SD}=0.47$ / $\mathrm{EG}: \mathrm{M}=3.27, \mathrm{SD}=0.48)$ and post- self-regulated learning skills scores (CG: $M=3.24, S D=0.44 / E G: M=3.41, S D=0.51)\left(p=0.259>0.05, \eta_{p}{ }^{2}=.026\right)$. Therefore, it can be deduced that flipped classroom approach did not cause any difference between the experimental and control group's self-regulated learning skills scores.

The self-regulated learning skills part consists of 3 subparts: before, during, and after study. In this respect, a comparative analysis was conducted between the before, during, and after study parts scores of the groups.

Table 11. Comparison of before study scores with mixed ANOVA

\begin{tabular}{ccccccc}
\hline Source & $\begin{array}{c}\text { Type III } \\
\text { Sum of } \\
\text { Squares }\end{array}$ & $\mathrm{df}$ & $\begin{array}{c}\text { Mean } \\
\text { Square }\end{array}$ & $\mathrm{F}$ & Sig. & Partial Eta Squared \\
\hline $\begin{array}{c}\text { Between } \\
\text { Groups }\end{array}$ & & & & & & .001 \\
\hline $\begin{array}{c}\text { Group (CG/ } \\
\text { EG) }\end{array}$ & .026 & 1 & .026 & .066 & .798 & \\
\hline Error & 18.989 & 48 & .396 & & \\
\hline
\end{tabular}

Note. ${ }^{*} p<.05,{ }^{* *} p<.01$ 
Table 11 indicated that there was statistically no significant difference between the groups with respect to their "before study" scores $\left(\mathrm{p}=0.798>0.05, \eta_{\mathrm{p}}{ }^{2}=.001\right)$. Hence, it can be deduced that flipped classroom approach did not cause any difference between the experimental and control group's "before study" pre-test (CG: $\mathrm{M}=3.28, \mathrm{SD}=0.65$ / EG: $\mathrm{M}=3.22, \mathrm{SD}=0.54$ ) and post-test scores (CG: $\mathrm{M}=3.31, \mathrm{SD}=0.53$ / EG: $\mathrm{M}=3.43, \mathrm{SD}=0.57)$.

Table 12. Comparison of during study scores with mixed ANOVA.

\begin{tabular}{ccccccc}
\hline Source & $\begin{array}{c}\text { Type III } \\
\text { Sum of } \\
\text { Squares }\end{array}$ & $\mathrm{df}$ & $\begin{array}{c}\text { Mean } \\
\text { Square }\end{array}$ & $\mathrm{F}$ & Sig. & Partial Eta Squared \\
\hline $\begin{array}{c}\text { Between } \\
\text { Groups }\end{array}$ & & & & & & .042 \\
\hline $\begin{array}{c}\text { Group (CG/ } \\
\text { EG) }\end{array}$ & .655 & 1 & .655 & 2.109 & .153 & \\
\hline Error & 14.896 & 48 & .310 & & \\
\hline
\end{tabular}

Note. ${ }^{*} p<.05,{ }^{* *} p<.01$

As for table 12, the findings presented that there was not any statistically significant difference between the groups regarding their "during study" pre-test (CG: $\mathrm{M}=3.26, \mathrm{SD}=0.44$ / $\mathrm{EG}: \mathrm{M}=3.34, \mathrm{SD}=0.58)$ and posttest (CG: $M=3.24, S D=0.45 / E G: M=3.49, S D=0.55)$ scores $\left(p=0.153>0.05, \eta_{p}{ }^{2}=.042\right)$, which can be interpreted as the fact that FCA did not create any difference between the experimental and control group's "during study" scores.

Table 13. Comparison of after study scores with mixed ANOVA

\begin{tabular}{ccccccc}
\hline Source & $\begin{array}{c}\text { Type III } \\
\text { Sum of } \\
\text { Squares }\end{array}$ & $\mathrm{df}$ & $\begin{array}{c}\text { Mean } \\
\text { Square }\end{array}$ & $\mathrm{F}$ & Sig. & Partial Eta Squared \\
\hline $\begin{array}{c}\text { Between } \\
\text { Groups }\end{array}$ & & & & & & .025 \\
\hline $\begin{array}{c}\text { Group (CG/ } \\
\text { EG) }\end{array}$ & .433 & 1 & .433 & 1.240 & .271 & \\
\hline Error & 16.782 & 48 & .350 & & & \\
\hline
\end{tabular}

Note. ${ }^{*} p<.05,{ }^{* *} p<.01$

Lastly, the findings presented in Table 13 indicated that there was not a statistically significant difference between the groups regarding their "after study" pre-test (CG: $M=3.02, S D=0.54$ / $E G: M=3.17, S D=0.48$ ) and post-test (CG: $M=3.14, S D=0.51 / E G: M=3.26, S D=0.61)$ scores $\left(p=0.271>0.05, \eta_{p}{ }^{2}=.025\right)$. Hence, it can be deduced that FCA did not create any difference between the experimental and control group's "after study" scores.

As for the second part of the study, the motivational factors, a comparative analysis was applied and the between-group statistics were presented to explore whether there was a statistically significant difference between the motivational factors scores of the groups due to the different teaching methods: traditional and flipped. 
Table 14. Comparison of motivational factors scores with mixed ANOVA

\begin{tabular}{ccccccc}
\hline Source & $\begin{array}{c}\text { Type III } \\
\text { Sum of } \\
\text { Squares }\end{array}$ & df & $\begin{array}{c}\text { Mean } \\
\text { Square }\end{array}$ & F & Sig. & Partial Eta Squared \\
\hline $\begin{array}{c}\text { Between } \\
\text { Groups }\end{array}$ & & & & & & \\
\hline $\begin{array}{c}\text { Group (CG/ } \\
\text { EG) }\end{array}$ & .047 & 1 & .047 & 230 & .634 & .005 \\
\hline Error & 9.893 & 48 & .206 & & & \\
\hline
\end{tabular}

Note. ${ }^{*} p<.05,{ }^{* *} p<.01$

The findings displayed in Table 14 showed that there was no statistically significant difference between the groups with respect to their motivational factors scores $\left(\mathrm{p}=.634>0.05, \mathrm{\eta}_{\mathrm{p}}{ }^{2}=.005\right)$. Therefore, the findings might indicate that FCA did not cause any difference between the experimental and control group's motivational factors pre-test (CG: $M=3.48, S D=0.40$ / $E G: M=3.41, S D=0.41)$ and post-test (CG: 3.39, $\mathrm{SD}=0.37$ / EG: $\mathrm{M}=3.55, \mathrm{SD}=0.47)$ scores.

\section{DISCUSSIONS AND CONCLUSION}

The purpose of this study was to investigate the impact of FCA on pre-service ELT teachers' overall L2 advanced writing achievement. In addition to this, the present study sought to explore its impact on students' self-regulated learning in a university setting. In an attempt to reach the objectives of the present study, the quantitative data of the study were gathered with the instruments of advanced writing pre-post-tests and self-regulated learning scale. Regarding whether there was a difference between EG and CG pre-service ELT teachers in terms of their self-regulated learning due to FCA, the quantitative results indicated that there was not any significant difference between the self-regulated learning pre-test and post-tests in CG and EG, which suggests that both CG and EG gave rise to an increase in their self-regulated learning. To put it differently, FCA did not lead to a statistically significant difference in self-regulated learning of EG and CG.

In the literature, studies related to the impact of FCA on self-regulated learning provide inconsistent results. In other words, in some studies it was stated that FCA had a positive impact on self-regulated learning of learners (Cakiroglu \& Ozturk, 2017; El-Senousy \& Alquda, 2018) and FCA both cultivates requires self- regulated learning (Hewitt, Journell, \& Zilonka, 2014). Ironically, some other studies indicated no impact of FCA on the self-regulated learning of learners (Sun et al., 2017; Elakovich, 2018). In this study, the insignificant difference of self-regulated learning levels between CG and EG may be attributed to the sampling characteristics. This argument conforms to the findings of the study (Alsancak-Sirakaya, 2015), which has shown that self-regulated learning results could have been different with different participants whose scores are average or below average. In this study, the pre-test scores of both groups were already high, which might have caused insignificant increase in self-regulated learning after the implementation. In a similar vein, Elakovich (2018) conducted a quasi-experimental research to compare students in a lecture remedial math course by applying the Motivated Strategies Learning Questionnaire (MSLQ) of Pintrich and Garcia (1991) in order to measure control of learning, self-efficacy and self-regulation. The results revealed that there was not a significant difference between the classes, which was interpreted as the requirements of the flipped classroom did not encourage learners to become more independent learners than the learners in the control group.

In conclusion, as there are a limited number of researches available in L2 setting, there is still a need for further investigation into the impact of FCA on self-regulated learning. As for the impact of FCA on the writing achievement of the participants, the results indicated that there was a significant difference between the scores of pre-test and post-test both in control and experimental groups, which suggests that both traditional lecture instruction and FCA gave rise to an increase in terms of participants' writing achievement. However, it was found out that the difference is higher in experimental group compared to the control group.

First of all, it can be concluded that implementation of FCA in writing classes enhances the writing ability of EFL learners. The data confirmed that FCA improves learners' writing proficiency. This study has also offered similar results with numerous current studies and research in the literature (Ekmekci, 2014; Ahmed, 2016; Leis, Cooke, \& Tohei, 2015; Abdelrahman, DeWitt, Alias, \& Rahman, 2017; Aji, 2017). 
The improvement in the participants' writing achievement might be attributed to FCA enabling individualized learning. To put it differently, as the learners were able acquire the knowledge by watching the videos whenever and wherever they wanted and as many times as they needed in accordance with their self-pacing, FCA had a positive impact on their writing achievement. This argument conforms to the findings of the study of Ekmekci (2017), which sought to explore the impact of FCA on learners' EFL writing skill which is often considered as boring, complicated and challenging by learners. The results of the study revealed that the students in the experimental had higher writing scores compared to the scores of the control group after the implementation of FCA. The study also indicated that learning is personalized in flipped learning environment and also, during the treatment process it was observed that almost each student learned at their self-pace and this model enabled them to discover their needs and styles. For instance, some students expressed that they watched the videos more than once while the others watched only once, which may be due to their self-pacing. In a similar vein, Ahmed (2016) found students benefited from critically analyzing key topics at their own pace in their comfort zones such as their homes and also that the experimental group outperformed the control group in the post-test of EFL writing and also the participants displayed positive attitudes towards flipping the writing class.

Another reason why FCA had a positive effect on the writing ability of the pre-service ELT teachers might be due to the fact that the learners were able to receive more and immediate feedback during the lesson as they did the exercises and wrote their essays in the classroom under the supervision of the course instructor. In this aspect, the results of this study are in accordance with those of the relevant studies (Leis et al., 2015; Ahmed, 2016; Ekmekci, 2017). Namely, the study aligns with Ahmed (2016) who found that FCA allows more in-class time to write in class, apply the things they have learned, and receive immediate feedback and guidance from the course instructor. Furthermore, Leis et al. (2015) conducted a study discussing the empirical results of a study comparing two English courses, one of which was taught via FCA and the other with traditional way at a Japanese university and discovered that FCA improves writing proficiency of learners and enables the teacher to provide more personalized advice and instruction as students wrote in the classroom. In a similar vein, in his study, Ekmekci (2017) discovered that promoting feedback options and time was an advantage of FCA and the results of his study revealed that the students in the flipped classroom were able to receive more immediate feedback via individual conferences, oral teacher feedback, and written comments, and also the in-class time was used more effectively and productively by dealing with each student individually and each student could receive peer, individual, and teacher feedback.

On the other hand, the results of this study indicated that FCA did not create and difference between the CG and EG in terms of their mechanics and use of English achievement. Regarding what led to this result, it is probably because the course mostly focused on the essay structure and content. Additionally, the fact that they attend a grammar lesson might have had a positive impact on the grammatical performance of both groups. However, the students in the flipped classroom outperformed the students in the traditional classroom in terms of their performance in introduction, body, and conclusion parts of the essay and coherence and cohesion, and vocabulary elements of the essay, which might be due to the advantages yielded by FCA based on the aforementioned researches.

In short, these findings are in accordance with the relevant literature. The results of the students confirmed that FCA is better than traditional writing class regarding writing achievement. However, further research is required for the detailed comparison of the parts in essays in order to find out whether it will lead to any increase in the mechanics and use of English part in other settings with other participants from various levels.

\section{Suggestions}

The present study significantly contributes to the literature by investigating the impact of flipped classroom approach on EFL writing achievement and self-regulated learning of pre-service English teachers. The results revealed that FCA makes a difference in writing achievement of the experimental group pre-service ELT teachers who were taught via FCA as compared to the control group taught via traditional lecture based instruction. However, it was discovered that flipped classroom approach does not create any difference between the self-regulated learning of the control and experimental groups.

As for recommendations for further research, the study can be replicated by training the students before the implementation of FCA and observing and measuring their use of self-regulated learning strategies by carrying out a comparative analysis of data gathered from an experimental group taught via FCA and a control group taught via traditional lecture instruction. Additionally, a larger sample with different proficiency levels studying 
at elementary, secondary or high schools, or prep classes at universities could also alter the results, which is suggested to be researched. Implementing FCA for a longer period of time could also impact the outcome.

Another important point to be considered is that before implementing FCA in a course, the teacher should receive training for FCA and learn how to adapt a course according to the FCA. The first step should be to set the objectives of the course clearly and design the syllabus based on these objectives and the FCA. Furthermore, during the whole process the objectives and the expected outcomes should be considered along with the reactions and reflections of the students. Additionally, before implementing FCA in a course, the teacher should make sure that the students are ready to use and for the use of technology in their lessons. Furthermore, all learners should be able to access internet and computer out of the classroom, whenever and wherever they want or need, and technical problems should also be eliminated. Otherwise, if the student cannot watch the videos before the classroom due to technical problems or absence, this problem may cause learning and student engagement hindrances.

Briefly, the findings of the present study illustrated that implementing flipped classroom approach for teaching writing could be regarded as an efficient way of instruction to support the development of writing skills in EFL classrooms. Therefore, it would be worth implementing FCA into EFL and ELT curriculum to assist with the development of writing. As a result, learners could be encouraged to perform better in their writing products and regulate their own learning process.

\section{BIODATA and CONTACT ADDRESSES of AUTHORS}

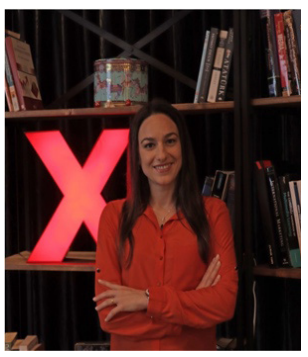

Dr. Ezgi Aydemir ALTAS is an English instructor at the School of Foreign Languages and Department of English Language Teaching (ELT), Yildiz Technical University, Istanbul, Turkey. She has been in the academic world for 11 years. Her research interests are teacher education, educational technology and the relationship between language and culture. She has authored a few articles in indexed journals and presented research studies in some distinguished conferences. She has been offering Basic English, English Language Programs and English for Mass Communication courses at the undergraduate level.

Ezgi Aydemir ALTAS

School of Foreign Languages, Department of Basic English

Address: Yildiz Technical University, 34210, Istanbul, Turkey

Phone: +90 5367317099

E-mail: ezgaydmr@yildiz.edu.tr

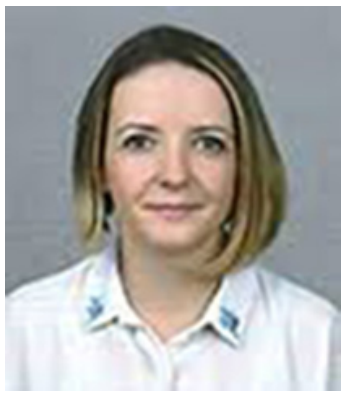

Dr. Enisa MEDE is an Associate Professor at the Department of English Language Teaching (ELT), Bahcesehir University, Istanbul, Turkey. She has been in the academia for 14 years. Her research interests lie in the area of program design and evaluation, bilingual education and first/second language development in young learners. She has authored numerous articles in indexed journals, published national and international book chapters and presented action research studies in numerous distinguished conferences. She has been offering Teaching Young Learners, School Experience and Teaching Practicum courses at the undergraduate level and Curriculum Development in Language Education, Syllabus Design and Second Language Acquisition courses at the graduate level.

Enisa MEDE

English Language Teaching, Faculty of Educational Sciences

Address: Bahcesehir University, 34353, Istanbul, Turkey

Phone: +90 5363957295

E-mail: enisamede@es.bau.edu.tr 


\section{REFERENCES}

Abdelrahman, L. A. M., DeWitt, D., Alias, N., \& Rahman, M. N. A. (2017). Flipped learning for ES L writing in a Sudanese school. Turkish Online Journal of Educational Technology- TOJET, 16(3), 60-70.

Abd Majid, F. (2007). SRL: Effective practices in ESL writing classes. Journal of Language Studies, 3, 115128.

Ahmed, M. A. E. A. S. (2016). The effect of a flipping classroom on writing skill in English as a foreign language and students' attitude towards flipping. US-China Foreign Language, 14(2), 98114.

Aji, M. P. P. (2017). Promoting flipped classroom model in teaching writing of EFL learners. KnE Social Sciences, 1(3), 279-291.

Almazloum, M. (2018). A Mixed Methods Study: The Impact of Self-Regulated Learningon L2 Writing and Strategy Use. Electronic Thesis and Dissertation Repository, 5355.

Alsancak-Sirakaya, D. (2015). The effect of flipped classroom model on academic achievement, self-directed learning readiness and motivation (Unpublished doctoral dissertation). Gazi University, Ankara.

Alsowat, H. (2016). An EFL flipped classroom teaching model: Effects on Englishlanguage higher-order thinking skills, student engagement and satisfaction. Journal of Education and Practice, 7(9), 108-121.

Anderson, L. W., Krathwohl, D. R., Airasian, P. W., Cruikshank, K. A., Mayer, R. E., Pintich, P. R., et al. (2001). A taxonomy for learning, teaching and assessing. A revision of Bloom's taxonomy of educational objectives. (Abridged edition ed.). New York: Longman.

Artino, A.R. (2008). Promoting academic motivation and self-regulation: Practical guidelines for online instructors. TechTrends, 52(3), 37-45.

Ary, D., Jacobs, L. C., Sorenson, C. K. \& Walker, D. (2013). Introduction to research in education. Belmont: Cengage Learning.

Bandura, A. (1986). Social foundation of thought and action. Englewood Cliffs: Prentice Hall.

Bandura, A. (1997). Self-efficacy: The exercise of control. Macmillan.

Barak, M. (2009, August). Fostering self-regulated learning in technological projects. In Conference proceeding, PATT - 22, strengthening technology education in the school curriculum - delft, the Netherlands.

Baranovic, K. (2013). Flipping the first-year composition classroom: Slouching toward the pedagogically hip (Doctoral dissertation, Southeast Missouri State University).

Barkley, B.W. (2010). The effects of blended online versus face-to-face learning environments on student outcomes for eighth grade algebra I students. (Doctoral dissertation). Retrieved from ProQuest. 3413019

Barone, C. A. (2003). Technology and the changing teaching and learning landscape: Meeting the needs of today's internet-defined students. American Association of Higher Education Bulletin.

Bergman, J., \& Sams, A. (2012). Flip your classroom: Reach every student in every class every day. n/l: ISTEInternational Society for Technology in Education.

Brame, C., (2013). Flipping the classroom. Vanderbilt University Center for Teaching. Retrieved from http:// cft.vanderbilt.edu/guides-sub-pages/flipping-the-classroom/.

Cakiroglu, U., \& Ozturk, M. (2017). Flipped classroom with problem based activities: Exploring selfregulated learning in a programming language course. Journal of Educational Technology \& Society, $20(1), 337$.

Carlisle, M. C. (2010). In G. Lewandowski (Chair). Using Youtube to enhance student participation in an introductory Java course. Paper presented at $41^{\text {st }}$ ACM Technical Symposium on Computer Science Education. doi: 10.1145/1734263.1734419 
Cashin, M. (2016). The Effect of Flipped Classrooms on Elementary Students' Reading Scores (Doctoral dissertation, Northcentral University).

Cigdem, H., Ozturk, M., \& Topcu, A. (2016). Self-regulation and interactivity types as the predictors of learner satisfaction with flipped courses: Evidence from a vocationalcollege. The Eurasia Proceedings of Educational \& SocialSciences, 5, 135-138.

Cole, J. E., \& Kritzer, J. B. (2009). Strategies for success: Teaching an online course. Rural Special Education Quarterly, 28(4), 36-40.

Condie, R., \& Livingston, K. (2007). Blending online learning with traditional approaches: $\mathrm{C} \mathrm{h}$ a $\mathrm{n}$ g i n g practices. British Journal of Educational Technology, 38(2), 337-348. doi: 10.1111/j.14678535.2006.00630.x

Ekmekci, E. (2014). Flipped writing class model with a focus on blended learning. Unpublished PhD Dissertation. Gazi University Graduate School of Educational Sciences, Ankara.

Ekmekci, E. (2017). The flipped writing classroom in Turkish EFL context: A comparative study on a new model. Turkish Online Journal of Distance Education, 18(2), 151-167.

Elakovich, D. M. (2018). Does a student's use of self-regulation change in the fipped classroom? (Doctoral dissertation, Montana State University-Bozeman, College of Education, Health \& Human Development).

Eppard, J., \& Rochdi, A. (2017). A Framework for Flipped Learning. International Association for Development of the Information Society.

El-Senousy, H., \& Alquda, J. (2017). The Effect of Flipped Classroom Strategy Using Blackboard Mash-Up Tools in Enhancing Achievement and Self-Regulated Learning Skills of University Students. World Journal on Educational Technology: Current Issues, 9(3), 144-157.

Engin, M., \& Donanci, S. (2014). Flipping the classroom in an academic writing course. Journal of Teaching and Learning with Technology, 94-98.

Erdogan, T., \& Senemoglu, N. (2016). Development and validation of a scale on self-regulation in learning (SSRL). SpringerPlus, 5(1), 1686.

Farah, M. (2014). The impact of using flipped classroom instruction on the writing performance of twelfth grade female Emirati students in the applied technology high school (ATHS) (Doctoral dissertation, The British University in Dubai (BUiD)).

Findlay-Thompson, S., \& Mombourquette, P. (2014). Evaluation of a flipped classroom in an undergraduate business course.

Finkel, E. (2012). Flipping the script in K12. District Administration, 48(10), 28.

Gannod, G. C. (2007). Work in progress: Using podcasting in an inverted classroom. Paper presented at Annual Frontiers in Education Conference, Milwaukee, WI.

Gannod, G. C., Burge, J. E., \& Helmick, M. T. (2008). Using the inverted classroom to teach soft w a $r$ e engineering (Technical Report No. MU-SEAS-CSA-2007-001). Oxford, OH: Miami University.

Garrison, D. R., \& Vaughan, N. D. (2008). Blended learning in higher education: Framework, principles, and guidelines. John Wiley \& Sons.

George-Walker, L. D., \& Keeffe, M. (2010). Self-determined blended learning: a case study of blended learning design. Higher Education Research \& Development, 29(1), 1-13.

Goodwin, B., \& Miller, K. (2013). Evidence on flipped classrooms is still coming in. Educational leadership, 70(6), 78-80.

Hadwin, A.F. (2008). Self-regulated learning. In T.L. Good (Ed.), 21stcentury education: A reference handbook (pp. 175-183). Thousand Oaks, CA: Sage Publications.

Heredia, K. (2015). The effects of the flipped classroom model on student academic growth in flipped and traditional community college classrooms. Unpublished $\mathrm{PhD}$ Dissertation. Aurora University College of Education, Illinois 
Hewitt, K. K., Journell, W., \& Zilonka, R. (2014). What the flip: impact of flipped instruction on selfregulated learning. IJSMILE, 2(4), 303-325.

Horton, W. K. (2000). Designing web-based training: How to teach anyone anything anywhere anytime (Vol. 1). New York, NY: Wiley.

Hung, H. T. (2015). Flipping the classroom for English language learners to foster active learning. Computer Assisted Language Learning, 28(1), 81-96.

Johnson, R. B., \& Christensen, L. B. (2004). Educational research: Quantitative, qualitative, and mixed approaches. Boston: Allyn and Bacon.

Johnson, L., \& Renner, J. (2012). Effect of the flipped classroom model on a secondary computer applications course: Student and teacher perceptions, questions and student achievement. (Unpublished doctoral dissertation. University of Louisville, Louisville, Kentucky).

Kellogg, S. 2009. Developing online materials to facilitate an inverted classroom approach. Paper presented at the annual Frontiers in Education Conference, San Antonio, TX.

Kenna, D. C. (2014). A study of the effect the flipped classroom model on student self-efficacy (Doctoral dissertation, North Dakota State University).

Lage, M. J., Platt, G. J., \& Treglia, M. (2000). Inverting the classroom: A gateway to creatingan inclusive learning environment. Journal of Economic Education, 31(1), 30-43. Retrieved from http://www. journalofeconed.org

Lee, S. W. Y., \& Tsai, C. C. (2011). Students' perceptions of collaboration, self-regulated learning, and information seeking in the context of Internet-based learning and traditional learning. Computers in human behavior, 27(2), 905-914.

Leis, A., Cooke, S., \& Tohei, A. (2015). The effects of flipped classrooms on English composition writing in an EFL environment. International Journal of Computer-Assisted Language Learning and Teaching (IJCALLT), 5(4), 37-51.

Liaw, S. S., \& Huang, H. M. (2013). Perceived satisfaction, perceived usefulness and interactive learning environments as predictors to self-regulation in e-learning environments. Computers \& Education, 60(1), 14-24.

Means, B., Toyama, Y., Murphy, R., Bakia, M., \& Jones, K., (2010). Office of Planning, Evaluation, and Policy Development. Evaluation of evidence-based practices in online learning: A meta-analysis and review of online learning studies. Retrieved from U.S. Department of Education website: www.ed.gov/about/offices/list/opepd/ppss/reports.html

Neumeier, P. (2005). A closer look at blended learning-parameters for designing a blended learning environment for language teaching and learning. ReCALL, 17(2), 163-178.

Nodoushan, M. A. S. (2012). Self-regulated learning (SRL): Emergence of the RSRLM model. Online Submission, 6(3), 1-16.

Pavanelli, R. (2018). The Flipped Classroom: A Mixed Methods Study of Academic Performanc and Student Perception in EAP Writing Context. International Journal of Language and Linguistics, 5(2), 16-26.

Pierce, R., \& Fox, J. (2012). Vodcasts and active-learning exercises in a "flipped classroom" model of a renal pharmacotherapy module. American journal of pharmaceutical education, 76(10), 196.

Pintrich, P. R. (1995). Understanding self-regulated learning. New directions for teaching and learning, 1995(63), 3-12.

Pintrich, P. R. (2000). The role of goal orientation in self-regulated learning. In Handbook of self-regulation (pp. 451-502). Academic Press.

Pintrich, P. R., \& Garcia, T. (1991). Student goal orientation and self-regulation in the college classroom. Advances in motivation and achievement: Goals and self-regulatory processes, 7(371-402). 
Quint, C. L. (2015). A study of the efficacy of the flipped classroom model in a university mathematics class (Doctoral dissertation, Teachers College, Columbia University).

Rasmussen, R. C. (2003). The quantity and quality of human interaction in a synchronous blended learning environment(pp. 1-156). Brigham Young University.

Rossett, A., Douglis, F., \& Frazee, R. V. (2003). Strategies for building blended learning. Learning circuits, 4(7), 1-8.

Ruddick, K. (2012). Improving chemical education from high school to college using a more hands-on approach. Unpublished doctoral dissertation, University of Memphis.

Sams, A., \& Bergmann, J. (2013). Flip your students' learning. Educational leadership, 70(6), 16-20.

Shibley, I. (2014). Putting the Learning in Blended Learning. In M. Bart (Eds.), Blended and Flipped: Exploring New Models for Effective Teaching \& Learning (pp. 4-5). Wisconsin: Magna Publications, Inc.

Singh, H. (2003). Building effective blended learning programs. Educational Technology-Saddle Brook Then Englewood Cliffs NJ-, 43(6), 51-54.

Snowden, K. E. (2012). Teacher perceptions of the flipped classroom: Using video lectures online to replace traditional in-class lectures (pp. 1-71). Denton, TX: University of North Texas.

Soliman, N. A. (2016). Teaching English for academic purposes via the flipped learning approach. ProcediaSocial and Behavioral Sciences, 232, 122-129.

Srivastava, K. (2014). Role of flipped classroom in education. Paripex Indian Journal of Research, 3(4), 8183. https://doi.org/10.15373/22501991/APR2014/27

Strayer, J. (2007). The effects of the classroom flip on the learning environment: A comparison of learning activity in a traditional classroom and a flip classroom that used an intelligent tutoring system (Doctoral dissertation, The Ohio State University).

Strayer, J. F. (2012). How learning in an inverted classroom influences cooperation, innovation and task orientation. Learning environments research, 15(2), 171-193.

Sun, J. C. Y., Wu, Y. T., \& Lee, W. I. (2017). The effect of the flipped classroom approach to Open Courseware instruction on students' self-regulation. British Journal of Educational Technology, 48(3), 713-729.

Szparagowski, R. (2014). The Effectiveness of the Flipped Classroom Exploring the Effectiveness of the Flipped Classroom. Honors Projects.

Tabrizi, S., \& Rideout, G. (2017). Active Learning: Using Bloom's Taxonomy to Support Critical Pedagogy. International Journal for Cross-Disciplinary Subjects in Education (IJCDSE), 8(3).

Trinder, R. (2012). Relating students' perceptions and use of ICT to their language learning aims. In Proceedings International Conference ICT for Language Learning (5th ed.) Retrieved from http://conference.pixelonlinenet/ICT4LL2012/common/download/Paper_pdf/136-LSP13FPTrinder-ICT2012.pdf

Tselios, N., Daskalakis, S., \& Papadopoulou, M. (2011). Assessing the acceptance of a blended learning university course. Journal of Educational Technology \& Society, 14(2), 224-235.

Tucker, B. (2012). The flipped classroom. Education next, 12(1), 82-83.

Ucar, H., \& Bozkurt, A. (2018). Donusturulmus sinif 2.0: bilginin uretimi ve sentezlenmesi. Egitimde Nitel Arastirmalar Dergisi - Journal of Qualitative Research in Education, 6(3), 143-157. DOI:10.14689/ issn.2148-2624.1.6c3s7m

Wang, F., \& Reeves, T. C. (2003). Why do teachers need to use technology in their classrooms? Issues, problems, and solutions. Computers in the Schools, 20(4), 49-65.

Warter-Perez, N., \& Dong, J. (2012). Flipping the classroom: How to embed inquiry and design projects into a digital engineering lecture. In Proceedings of the 2012 ASEE PSW Section Conference (Vol. 39). Washington DC: American Society for Engineering Education. 
Watson, J., (2008). Blended learning: The convergence of online and face-to-face education. Vienna, VA: North American Council for Online Learning.

Webb, M., \& Doman, E. (2016). Does the Flipped Classroom Lead to Increased Gains on Learning Outcomes in ESL/EFL Contexts? CATESOL Journal, 28(1), 39-67.

Wiginton, B. (2013). Flipped instruction: An investigation into the effect of learning environment on student self-efficacy, learning style, and academic achievement in an algebra I classroom (Doctoral dissertation, University of Alabama Libraries).

Zappe, S., Leicht, R., Messner, J., Litzinger, T., \& Lee, H. W. (2009). Flipping. In the classroom to explore active learning in a large undergraduate course. In Paper presented at the American society for engineering education annual conference and exhibition, Austin, TX.

Zhu, W. (2004). Faculty views on the importance of writing, the nature of academic writing, and teaching and responding to writing in the disciplines. Journal of second language Writing, 13(1), 29-48.

Zimmerman, B. J. (1990). Self-regulated learning and academic achievement: An overview. Educational psychologist, 25(1), 3-17.

Zimmerman, B. J. (2000). Attaining self-regulation: A social cognitive perspective. In M. Boekaerts, P. R. Pintrich, \& M. Zeidner (Eds.), Handbook of self-regulation (pp. 13-39). San Diego: Academic Press.

Zimmerman, B. J. (2001). Theories of SRL and academic achievement: An overview and analysis. In B. J. Zimmerman and D. H. Schunk (Eds.), SRL and academic achievement: Theoretical perspectives (pp. 1-37). New York, NY: Lawrence Erlbaum Associates. 